Article

\title{
Experimental Investigations of Interactions between Sand Wave Movements, Flow Structure, and Individual Aquatic Plants in Natural Rivers: A Case Study of Potamogeton Pectinatus L.
}

\author{
Łukasz Przyborowski ${ }^{1}$, Anna Maria Łoboda ${ }^{1}$ (D) and Robert Józef Bialik ${ }^{2, *}$ (iD) \\ 1 Institute of Geophysics, Polish Academy of Sciences, Księcia Janusza 64, 01-452 Warsaw, Poland; \\ lprzyborowski@igf.edu.pl (Ł.P.); aloboda@igf.edu.pl (A.M.Ł.) \\ 2 Institute of Biochemistry and Biophysics, Polish Academy of Sciences, Pawińskiego 5a, \\ 02-106 Warsaw, Poland \\ * $\quad$ Correspondence: rbialik@ibb.waw.pl; Tel.: +48-22-592-5796
}

Received: 5 August 2018; Accepted: 28 August 2018; Published: 30 August 2018

\begin{abstract}
Long-duration measurements were performed in two sandy bed rivers, and three-dimensional (3D) flow velocity and bottom elevation changes were measured in a vegetated area and in a clear region of a river. Detailed flow velocity profiles downstream and upstream of a single specimen of Potamogeton pectinatus L. were obtained and the bed morphology was assessed. Potamogeton plants gathered from each river were subjected to tensile and bending tests. The results show that the existence of the plants was influenced by both bottom and flow conditions, as the plants were located where water velocity was lower by $12 \%$ to $16 \%$ in comparison to clear region. The characteristics of the flow and sand forms depended on the cross-sectional arrangement of the river, e.g., dunes were approximately four times higher in the middle of the river than in vegetated regions near the bank. Furthermore, the studied hydrophytes were too sparse to affect water flow and had no discernible impact on the sand forms' movements. The turbulent kinetic energy downstream of a single plant was reduced by approximately $25 \%$. Additionally, the plants' biomechanical characteristics and morphology were found to have adjusted to match the river conditions.
\end{abstract}

Keywords: aquatic plants; flow velocity measurements; river morphology; acoustic Doppler velocimeter; natural sandy bed river; sand waves; turbulent kinetic energy; aquatic plant biomechanics

\section{Introduction}

Aquatic plants grow in various configurations in rivers, affecting a variety of biological, chemical, and physical processes [1]. They influence both river morphodynamics and flow hydrodynamics by trapping sediments, preventing erosion, affecting turbulent flow fields, and contributing to overall bed roughness, as reported in numerous studies, e.g., [2-8]. One of the most important conclusions of these studies was that the understanding of flow-biota-sediment interactions requires an interdisciplinary approach. O'Hare et al. [9] emphasized that linking plant traits with physical modeling is an example of such multidisciplinary research, where ecological variability is a valid factor. Furthermore, Reid and Thoms [10] highlighted the need to obtain three-dimensional (3D) velocity and turbulence measurements to properly describe river habitats.

In vegetated rivers, sediment transport and channel morphodynamics are affected by vegetation $[1,11]$. In a vegetated location, the bed load is expected to diffuse transversely into the vegetation and deposit in the lee side of the patches [12], with increased erosion at the lateral sides of the patches, constituting the so-called scouring effect [13]. Suspended sediment is prone to being deposited in the wake of 
vegetation [14]. Bouma et al. [15] observed high turbulence and erosion at the leading edges and sides of patches of epibenthic structures such as Spartina anglica tussocks. This intertidal vegetation strongly reduced the water velocity, resulting in sedimentation farther downstream. Moreover, Rominger et al. [13] described how vegetative drag diverges and accelerates the flow, potentially causing erosion at the patch edge, which is similar to the scour patterns observed in the field around individual flow obstructions such as bridge piers. In addition, Schnauder and Sukhodolov [16] investigated the seasonal patch effect on sediment transport and concluded that although plant patches affected the transverse flow profiles near the edges, pool scouring did not occur; however, sediment was observed to accumulate in the recirculation zones. Additional data were reported by Cavedon [17], who, based on laboratory experiments, concluded that for a sufficiently high density of stems, the length of bed forms was not influenced by vegetation density, but only by the distance between plants. Velocity profiles in vegetated channels change throughout the year due to plant growth and senescence, therefore shear velocity influencing beds also varies [18]. Our investigation revealed that the height of the forms is reduced first in the vegetated parts of a river. Then it depends on vegetation density and is strongly coupled to the characteristics of the flow field and sediment properties. However, this phenomenon requires further analysis, particularly in natural field conditions.

From a broader perspective, the sedimentation rates in a river are time-dependent, thus natural aquatic habitat characteristics always depend on flow, biota, and morphodynamic feedback over a certain time scale $[5,19]$. Consequently, the species living in these habitats are called ecosystem engineers because of their control over flow velocity and sediment deposition [20]. To find patterns in the changing and complex ecosystem of a vegetated river, most researchers have focused on flume experiments (e.g., [8,21-23]), and only a few have conducted similar measurements in natural rivers (e.g., [24,25]). Such experiments are typically conducted using an acoustic Doppler velocimeter (e.g., [24,26-29]), which allows measurement of the velocity field at discrete points over bed forms. Although this device was built for laboratory purposes, it is usable in the field (e.g., [30]), albeit with certain limitations in its use and in interpreting the acquired data [31,32]. One can characterize changes in bed structure using either a discrete or continuous approach [33,34]. In the present study, the former approach was used to characterize bed forms in terms of height, length, and celerity, using the echo-sounding ability of current profiler and velocity profiler.

The main goal of this study was to evaluate changes and differences in sand wave movements and flow in vegetated and unvegetated parts of a channel cross-section with regard to sediment composition, flow dynamics, and bed morphology in two natural lowland rivers. This was achieved by recording these changes with long-duration point measurements of 3D velocity and bed elevation, and by scanning bed morphology in chosen parts of rivers with aquatic plants, which gave sufficient quantitative and qualitative information about the investigated subject. Moreover, the biomechanical features of a chosen aquatic macrophyte were studied to investigate how these characteristics differ between plants collected from two distinct river habitats. Due to the challenges inherent in the task of studying multiple aspects of a river ecosystem simultaneously, this case study also represents an attempt to identify the needs and limitations in a multidisciplinary investigation of flow-biota-sediment interactions in field conditions.

\section{Materials and Methods}

\subsection{Equipment}

Measurement of the instantaneous three-dimensional (3D) velocity field and recording of the bottom elevation were performed using a Vectrino Profiler (VP) (revision 2779/1.32, Nortek AS, Rud, Norway). The following VP setup parameters were chosen: Recording frequency of $25 \mathrm{~Hz}$, minimum ping algorithm with high power level, and velocity range up to $0.1 \mathrm{~m} \cdot \mathrm{s}^{-1}$ above the maximum observed longitudinal velocity during a trial. VPs were mounted on a steel platform. In addition, the bathymetry and velocity spatial distribution of the rivers were obtained using an acoustic Doppler current profiler 
(ADCP), RiverSurveyor S5 model (SonTek, San Diego, CA, USA). The grain-size distribution was measured using a laboratory shaker with a standard sieve set $(10 \mathrm{~mm}, 2 \mathrm{~mm}, 1 \mathrm{~mm}, 0.50 \mathrm{~mm}, 0.25 \mathrm{~mm}$, $0.10 \mathrm{~mm}$, and $0.071 \mathrm{~mm}$ mesh). Before sieving, the sediment sample was dried at $105^{\circ} \mathrm{C}$.

\subsection{Study Sites}

The first experiment was conducted on the Jeziorka River on 4 July 2017. This river is located south of Warsaw $\left(52^{\circ} 04^{\prime} 55.2^{\prime \prime} \mathrm{N}, 21^{\circ} 04^{\prime} 02.4^{\prime \prime} \mathrm{E}\right)$. The vegetation in this location covered no more than $20 \%$ of the channel cross-section. The water temperature $\left(\sim 15^{\circ} \mathrm{C}\right)$ and other basic characteristics of the river, as well as bed morphology in regard to actual water depth, were measured using the ADCP (Table 1). Bed sediment samples from 3 random locations across the river were taken to conduct granulometry and were found to consist of fine, moderately sorted sand with $D_{16}=0.11 \mathrm{~mm}, D_{50}=0.20 \mathrm{~mm}$, and $\mathrm{D}_{84}=0.39 \mathrm{~mm}$, and an inclusive graphic standard deviation equal to 0.848 (Figure 1).

The platform in the first part of the experiment, where the velocities in the whole water depth were measured, was placed parallel to the flow, above a single specimen of P. pectinatus. Measurements were conducted at a point located $20 \mathrm{~cm}$ upstream of the plant and at points 25 and $50 \mathrm{~cm}$ downstream, in the wake of the plant, in which flow is supposedly affected by it. Recording of velocity in each point of the velocity profile lasted $3 \mathrm{~min}$. The hydrophyte was then collected for further biomechanical testing.

In the second part of the experiment, the platform was placed perpendicular to the flow. The first VP was placed $20 \mathrm{~cm}$ in front of another specimen of P. pectinatus in a $55 \mathrm{~cm}$ deep vegetated region in the river adjacent to the right bank, where the majority of the plants grew (Figure 2). The second device was placed near the middle of the river, where the bed was bare. With both probes positioned $15 \mathrm{~cm}$ above the bottom level, the velocities and bottom elevation changes were measured for $1.5 \mathrm{~h}$. A survey of the river bottom adjacent to the right bank revealed many small specimens of P. pectinatus and a substantial amount of debris, mostly in the form of dead wood in the vegetated region.

The second experiment was conducted on the Świder River $\left(52^{\circ} 07^{\prime} 59.2^{\prime \prime} \mathrm{N}, 21^{\circ} 15^{\prime} 41.5^{\prime \prime} \mathrm{E}\right)$ on 1 October 2017. The riverbed in this location was covered with sand and was almost clear of plants, which grew only along the left bank. The water temperature $\left(\sim 11.6^{\circ} \mathrm{C}\right)$ and other basic characteristics of the river, as well as bed morphology regarding actual water depth, were measured using ADCP (Table 1). In addition to P. pectinatus, two other species (Myriophyllum spicatum L. and Potamogeton crispus L.) were also found growing downstream at the left bank. The platform was oriented perpendicular to the flow, $1 \mathrm{~m}$ from the left bank (Figure 3). The first velocimeter was positioned $10 \mathrm{~cm}$ upstream along a $0.6 \mathrm{~m}$ long and $1 \mathrm{~m}$ wide strip where P. pectinatus specimens were located. The second velocimeter was placed in a clear region $3 \mathrm{~m}$ from the first one. The bed elevation and velocity recording lasted $3 \mathrm{~h}$.

Granulometry revealed that the bed sediment in the Świder River consisted of medium poorly sorted sand with $\mathrm{D}_{16}=0.14 \mathrm{~mm}, \mathrm{D}_{50}=0.24 \mathrm{~mm}$, and $\mathrm{D}_{84}=0.47 \mathrm{~mm}$, and an inclusive graphic standard deviation equal to 1.02 (Figure 1).

Table 1. Basic hydraulic statistics of the studied rivers in the experimental locations.

\begin{tabular}{|c|c|c|c|c|c|c|}
\hline & $\begin{array}{l}\text { Mean } U \\
\left(\mathrm{~m} \cdot \mathrm{s}^{-1}\right)\end{array}$ & $\begin{array}{c}\text { Discharge } \\
Q\left(\mathrm{~m}^{3} \cdot \mathrm{s}^{-1}\right)\end{array}$ & Mean $H(\mathrm{~m})$ & $\begin{array}{l}\text { Width } \\
\text { (m) }\end{array}$ & $\begin{array}{c}\text { Reynolds } \\
\text { Number } \\
\left(\mathrm{U} \cdot \mathrm{H} \cdot v^{-1}\right)\end{array}$ & $\begin{array}{c}\text { Froude } \\
\text { Number } \\
\left(\mathrm{U} \cdot(\mathrm{H} \cdot \mathrm{g})^{-0.5}\right)\end{array}$ \\
\hline Jeziorka R. & 0.30 & 2.01 & 0.6 & 11 & $1.58 \times 10^{5}$ & 0.123 \\
\hline Świder R. & 0.51 & 4.26 & 0.46 & 18 & $1.88 \times 10^{5}$ & 0.24 \\
\hline
\end{tabular}




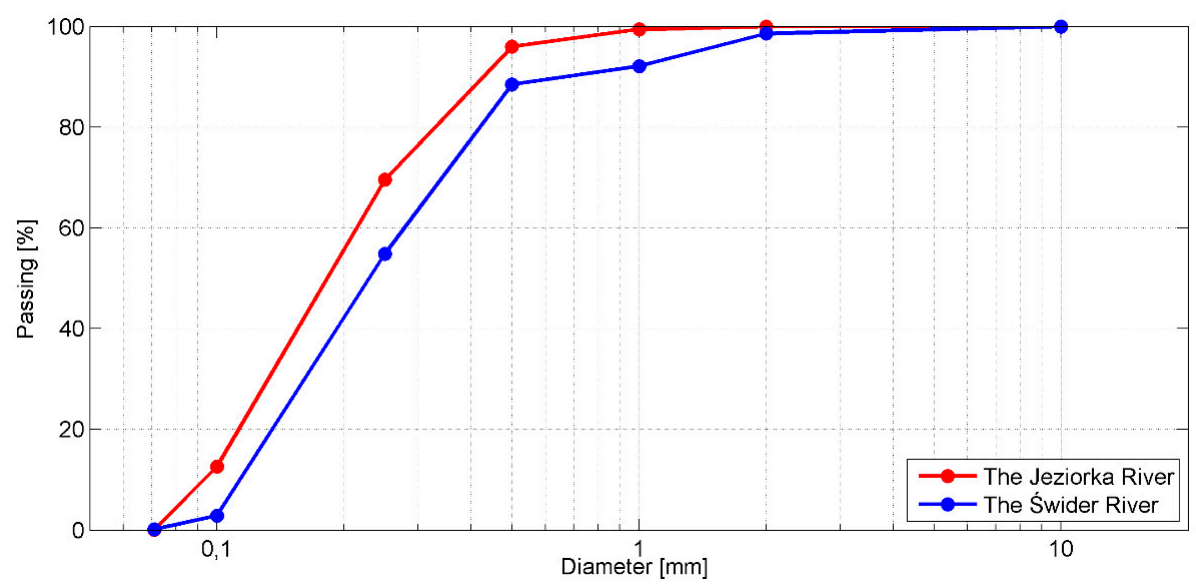

Figure 1. Granulometric distribution curves of bed sediment collected from the Jeziorka and Świder Rivers.

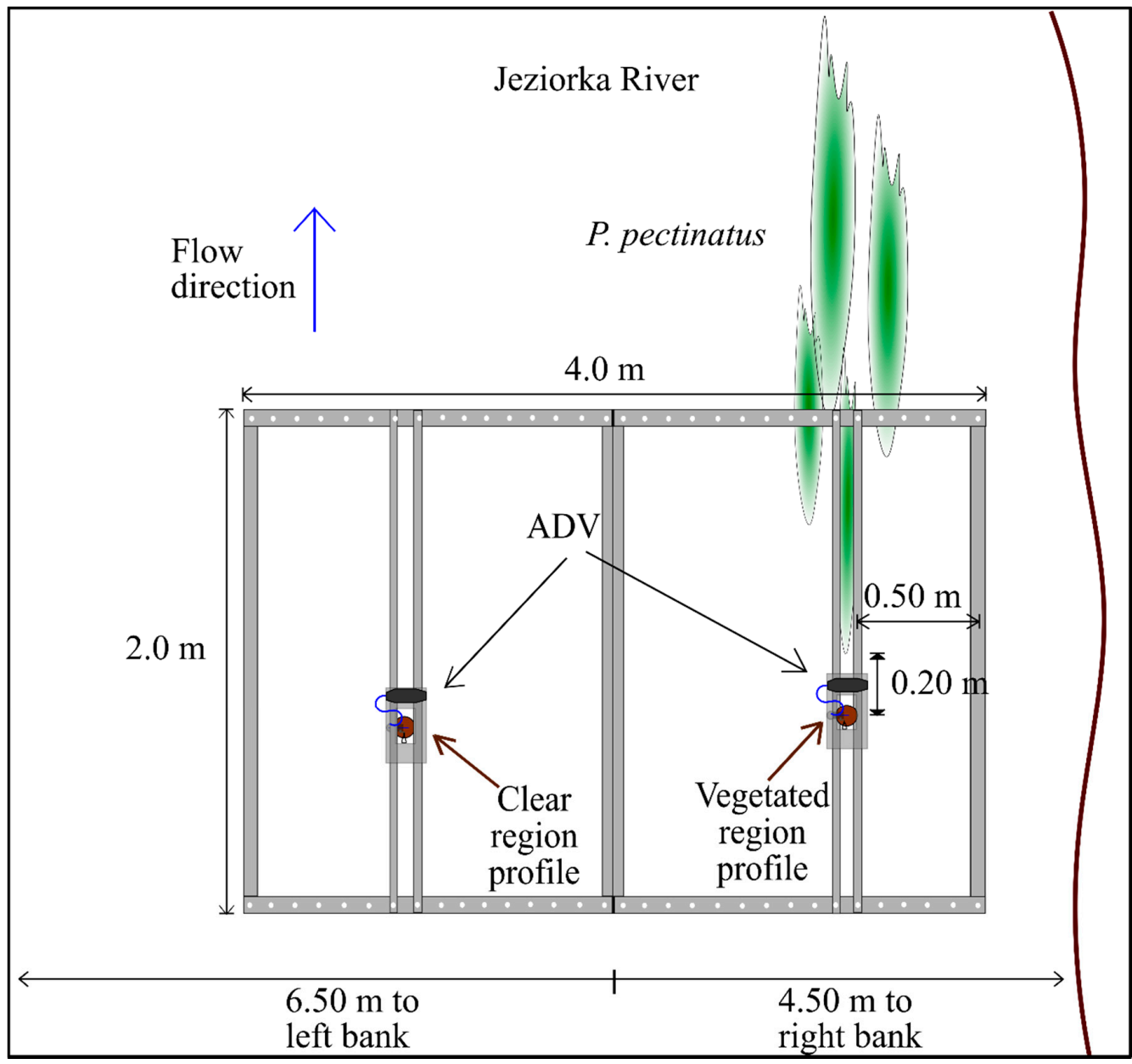

Figure 2. Arrangement of the platform with Vectrino Profilers and individuals of P. pectinatus during the experiment in the Jeziorka River (second part).

\subsection{Plant Characterization}

Hydrodynamic measurements were conducted near the same aquatic plant species, P. pectinatus, which is a slender, submerged macrophyte [35]. Each field experiment was followed by laboratory measurements of biomechanical traits. 
In the Jeziorka River, the chosen individual plant had a length of $1 \mathrm{~m}$ and floated almost horizontally approximately 10 to $20 \mathrm{~cm}$ above the bottom. Other macrophytes in the vegetated region of the channel grew in a dense patch $5 \mathrm{~m}$ in length, and their stems floated higher above the bottom than the tested hydrophyte. In the Świder River, individuals of P. pectinatus were much shorter, with an average length of $35 \mathrm{~cm}$. The investigated plants grew in a different pattern than the macrophytes in the Jeziorka River; instead of one slender and long patch, the plants were spread across a $1.5 \mathrm{~m}$ wide and $0.6 \mathrm{~m}$ long area (Figure 3), with stems floating at a maximum of $5 \mathrm{~cm}$ above the riverbed.

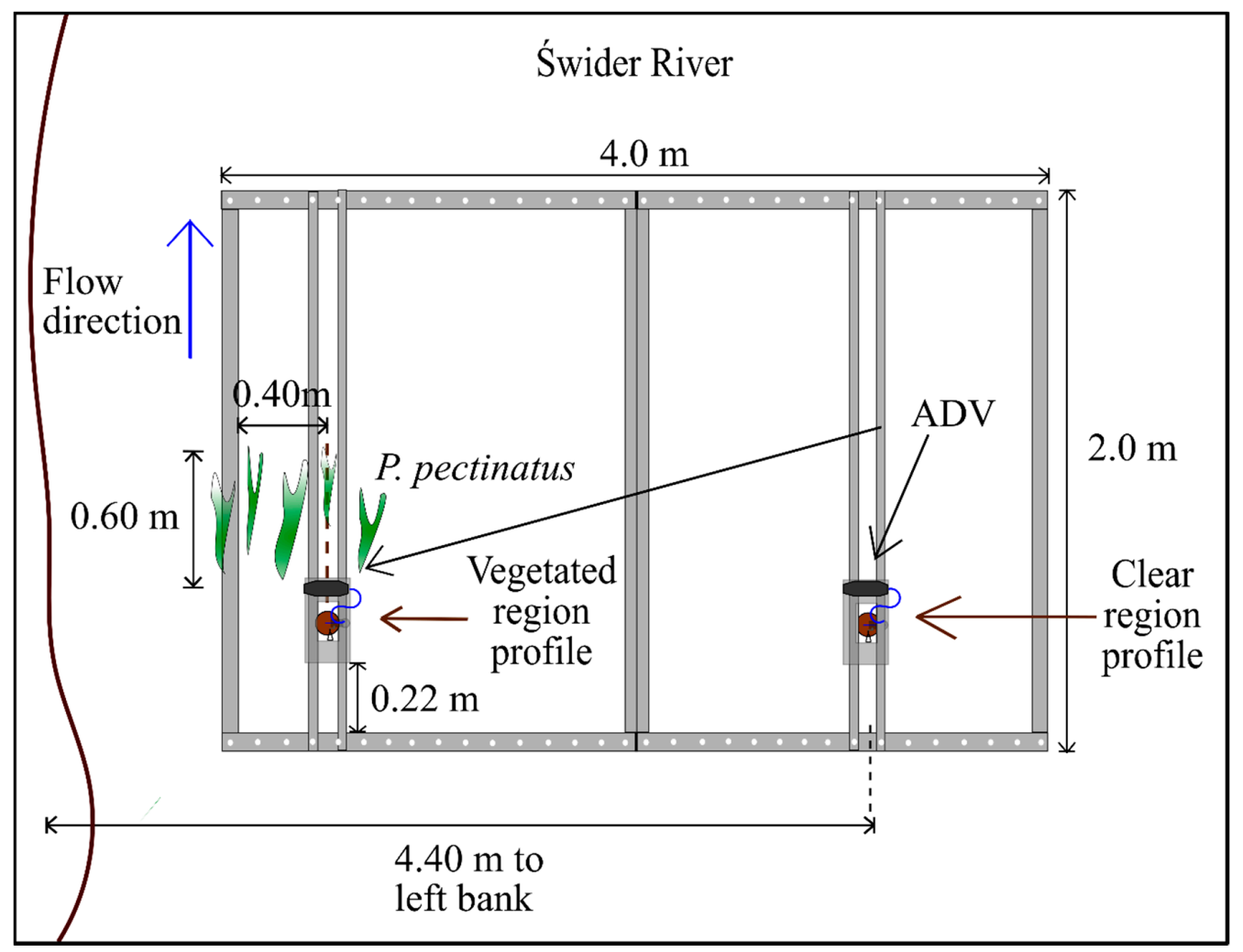

Figure 3. Arrangement of the platform with Vectrino Profilers and individuals of P. pectinatus during the experiment in the Świder River.

\subsection{Measurements of Biomechanical Traits}

Biomechanical tests (3-point bending and tension tests) were conducted using a Tinius Olsen Bench Top Testing Machine, 5ST Model (Tinius Olsen, Redhill, UK), and the data were recorded using Horizon software. The plants were transported to the laboratory and kept in a $112 \mathrm{~L}$ tank (more details are available in [36]). After a plant was removed from the aquarium, the stem was cut into $7 \mathrm{~cm}$ pieces. Next, the diameter of each sample was measured using a microscope. In the tension tests, short strips of sandpaper were glued to the ends of the samples to prevent them from slipping out of the machine clamps [36]. The measurements were conducted in submerged conditions [36]. In addition, to minimize the time interval between removing a plant from the aquarium and conducting the test, no more than 10 samples were prepared at the same time.

The investigated parameters in the 3-point bending test included maximum force, maximum stress, maximum deflection, flexural strain, flexural rigidity, and flexural modulus, and the tension parameters included breaking force, stress and strain, and Young's modulus. All parameters were calculated following formulas from Łoboda et al. [36], based on Niklas [37] and ASTM [38]. 


\subsection{Data Processing}

The VP was used to record velocities in a profile placed $11 \mathrm{~cm}$ above the bottom at the start of the measurement in the Jeziorka River and $15 \mathrm{~cm}$ in the Świder River. The depth was chosen to perform measurements in a water volume as close to the bottom as possible, but without danger of burying the probe. In case of profiles upstream and downstream of P. pectinatus in the Jeziorka River, each point in the profile represented a 3-min recording, and the vertical distance between the following points was $3 \mathrm{~cm}$. The collected datasets were then processed and filtered before further analysis. Parts of code included in the MITT open source MATLAB algorithms [39] were used for velocity data processing. The time-dependent analysis of the recorded velocity data revealed significant drops in data quality caused by noise that affected certain VP beams. Thus, a significant part of velocity data records was discarded during the second experiment.

To exclude spikes in the velocity records from the VP, a 3-stage method was used. First, from each measurement point containing 30 cells within it, one cell within the "sweet spot" was identified with the best signal-to-noise ratio (SNR) value $[32,40,41]$ and subjected to further processing. Second, points in the recording with correlation below $70 \%$ and SNR values below $15 \mathrm{~dB}$ were discarded and replaced using linear interpolation. The last step included using the modified 3D phase-space thresholding method filter to remove the spikes [42-44].

After the filtering, the following flow characteristics were calculated: Mean velocity, standard deviation of velocity, turbulent kinetic energy, turbulence intensity, and Reynolds stress (Tables 3 and 4). The turbulent kinetic energy (TKE) was calculated as:

$$
\mathrm{TKE}=\frac{1}{2}\left(\overline{\left(U^{\prime}\right)^{2}}+\overline{\left(V^{\prime}\right)^{2}}+\overline{\left(W^{\prime}\right)^{2}}\right)
$$

where $U^{\prime}, V^{\prime}$, and $W^{\prime}$ are velocity fluctuations in the longitudinal, lateral, and vertical directions, respectively, and the overbars denote mean values. Normal Reynolds stresses, turbulence intensities, and TKE were calculated as noise free, which was possible due to redundant data of 2 independent vertical velocities recorded by VP $[45,46]$. As the first vertical velocity was obtained from the same pair of beams as longitudinal velocity, it was used for all relevant calculations [41].

The power spectral densities were calculated using scripts implemented in MATLAB, i.e., the Welch [47] method with discrete Fourier transform points equal to 512, with 50\% overlap and a Hamming window function [41].

The characteristics of the bed forms were calculated from the data acquired by the current profiler, where the lengths of forms were given as the height from the local maximum crest to the local minimum trough [48]. The mean celerity of the bed forms was estimated from the current profiler and VP records and was calculated using the equation proposed by Nikora et al. [33]:

$$
C=\frac{0.66 \bar{U} F r^{2.9}}{\frac{g \lambda}{-2}}
$$

where $\bar{U}$ is mean velocity, $F r$ is the Froude number, $g$ is gravitational acceleration, and $\lambda$ is the length of a bed form.

\section{Results}

\subsection{Bed Elevation Long-Duration Behavior and Bed Morphology}

The bed morphology revealed by a river cross-section (Figure 4) showed uneven elevations near the left bank of the river and a relatively flat bottom through the middle part up to the deepest section near the right bank, where the majority of the P. pectinatus specimens grew. The results from the 
experiment conducted in the Jeziorka River showed fluctuations of the bed elevation of less than $0.5 \mathrm{~cm}$ in the vegetated area and up to $2 \mathrm{~cm}$ in the clear area (Figure 5).

The experiment conducted in the Świder River showed ripples 1.0 to $2.5 \mathrm{~cm}$ high in the vegetated area (Figure 6). In the clear region, no distinct ripples were observed. In the clear region, a sand dune $10 \mathrm{~cm}$ high was observed (Figure 6). The occurrence of smaller ripples was then observed on the upstream side of that sand form, which were clearly distinguishable as a second type of wave form $[33,49]$. The streamwise depth elevation profiles revealed easily distinguishable deep and shallow areas close to the bank (Figure 4, profile I in Figure 7). Moving away from the bank, profile II, which was at the same distance from the bank as the long-duration measurement point in the vegetated area, showed continuous changes in elevation approximately $3 \mathrm{~cm}$ high. Profile IV, which was at the same distance from bank as the long-duration measurement point in the clear area, showed a series of dunes $10 \mathrm{~cm}$ high. Both profiles II and IV were thus consistent with time-dependent changes in the vegetated and clear regions (Figure 6). The measured properties of the sand forms showed that height and length increased with increasing distance from the channel's left bank, while dune celerity decreased (Table 2, Figure 7).

Table 2. Statistics of sand waves in the considered profiles in the Świder River. L denotes length of a dune; $\mathrm{H}$ denotes height of the dune; SD denotes standard deviation.

\begin{tabular}{cccccccc}
\hline Location & $\begin{array}{c}\text { Mean } L \\
(\mathbf{c m})\end{array}$ & $\begin{array}{c}\text { Mean } H \\
(\mathbf{c m})\end{array}$ & $\begin{array}{c}\text { SD } \mathbf{L} \\
\mathbf{( c m )}\end{array}$ & $\begin{array}{c}\text { SD } H \\
(\mathbf{c m})\end{array}$ & $\begin{array}{c}\text { Mean } \\
\text { Time } \boldsymbol{\tau}(\mathbf{s})\end{array}$ & $\begin{array}{c}\text { Celerity } \\
\left(\mathbf{m s}^{-\mathbf{1}} \times \mathbf{1 0}^{\mathbf{3}} \mathbf{)}\right.\end{array}$ & $\begin{array}{c}\text { Theoretical } \\
\text { Celerity } \\
\left(\mathbf{m s}^{-\mathbf{1}} \times \mathbf{1 0}^{\mathbf{3}} \mathbf{)}\right.\end{array}$ \\
\hline Profile II & 127.1 & 3.2 & 36.0 & 2.2 & 1338 & 0.949 & 0.112 \\
Profile III & 257.5 & 12.8 & 67.9 & 5.2 & - & - & - \\
Profile IV & 345.8 & 13.2 & 138.5 & 4.0 & 10.400 & 0.332 & 0.041 \\
\hline
\end{tabular}

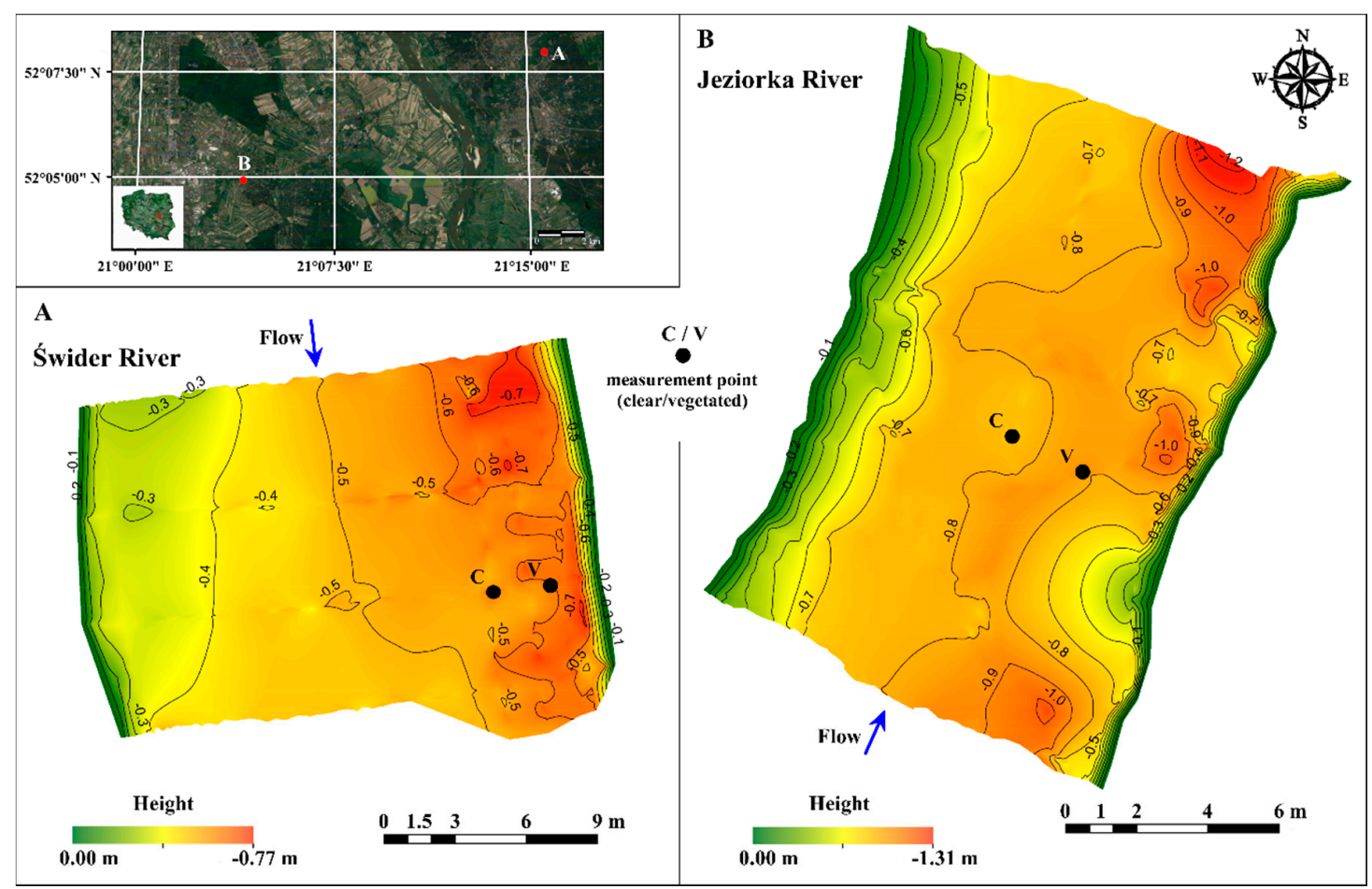

Figure 4. Bed morphology of studied sites in the (A) Świder River and (B) Jeziorka River. 

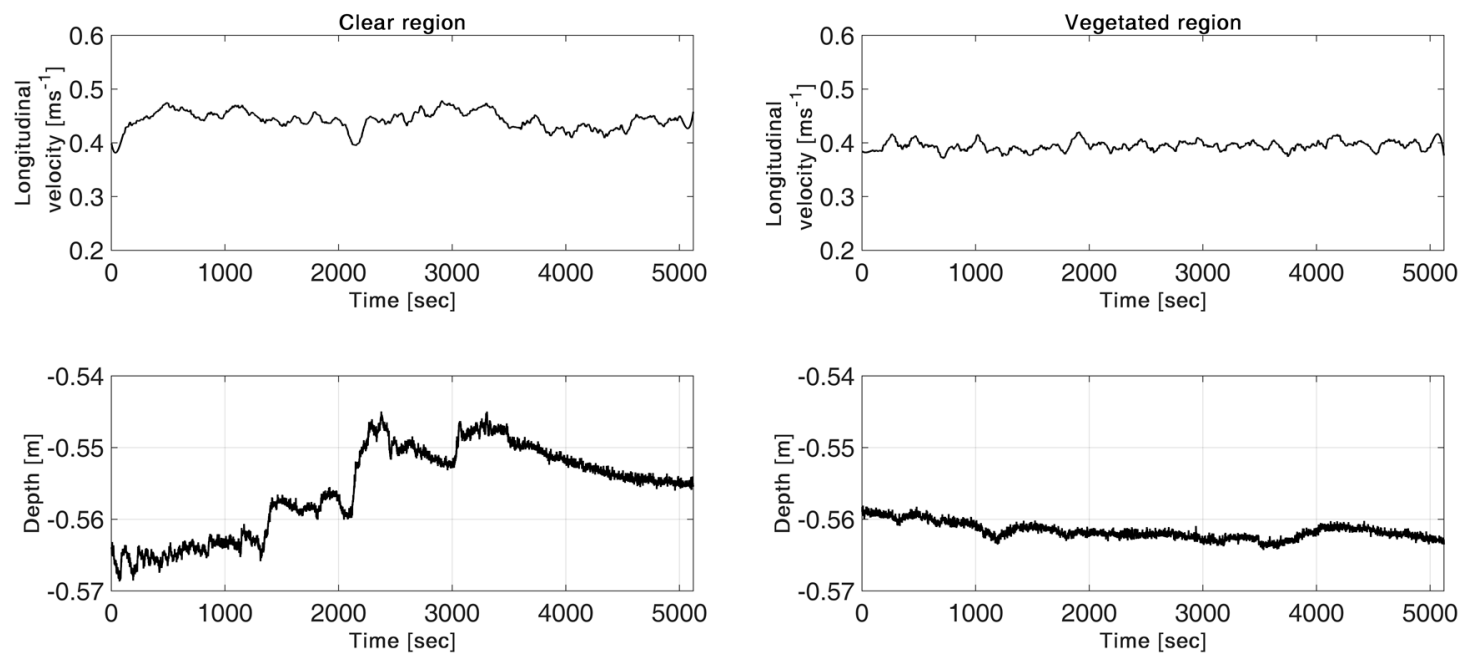

Figure 5. Smoothed longitudinal velocity and depth changes in the Jeziorka River at one point in clear, and one in vegetated region.
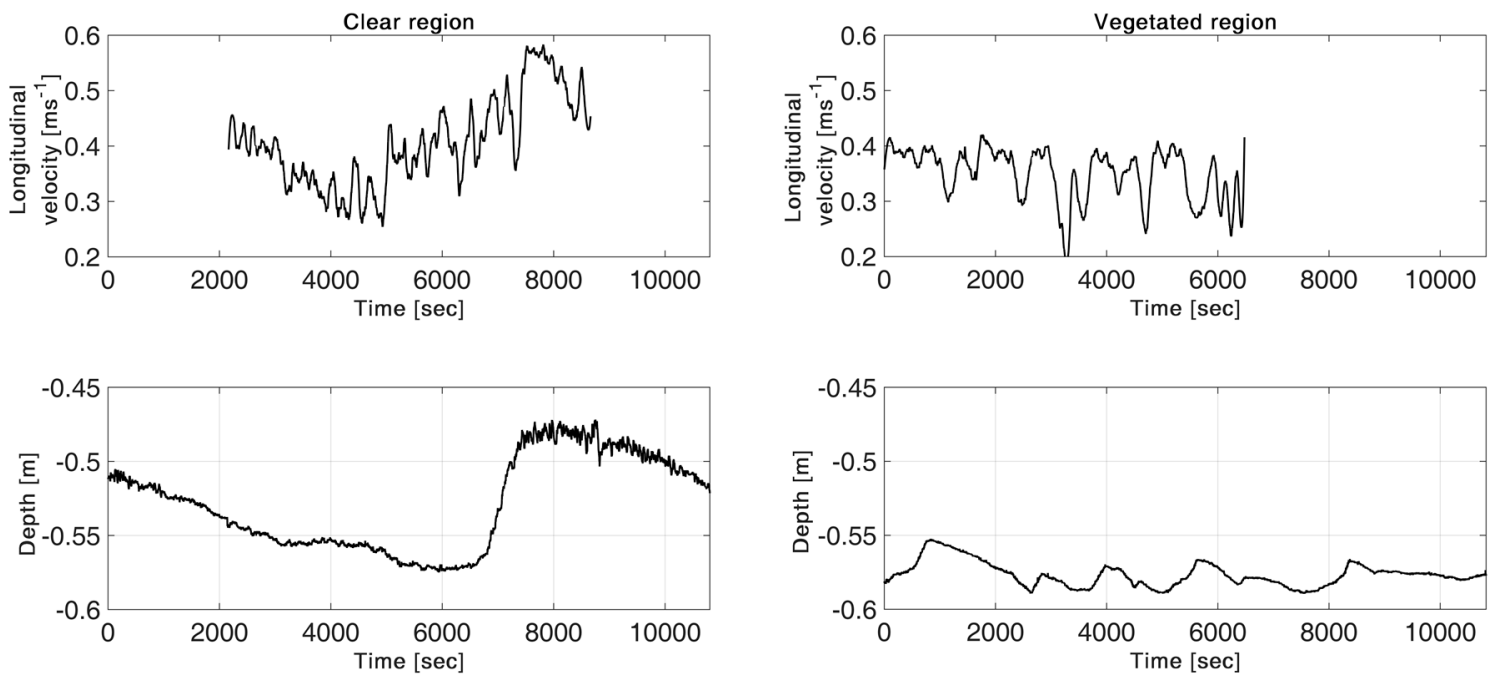

Figure 6. Smoothed longitudinal velocity and depth changes in the Świder River at one point in clear, and one in vegetated region. Parts of the velocity recording were removed due to bad signal characteristics. 
FLOW -
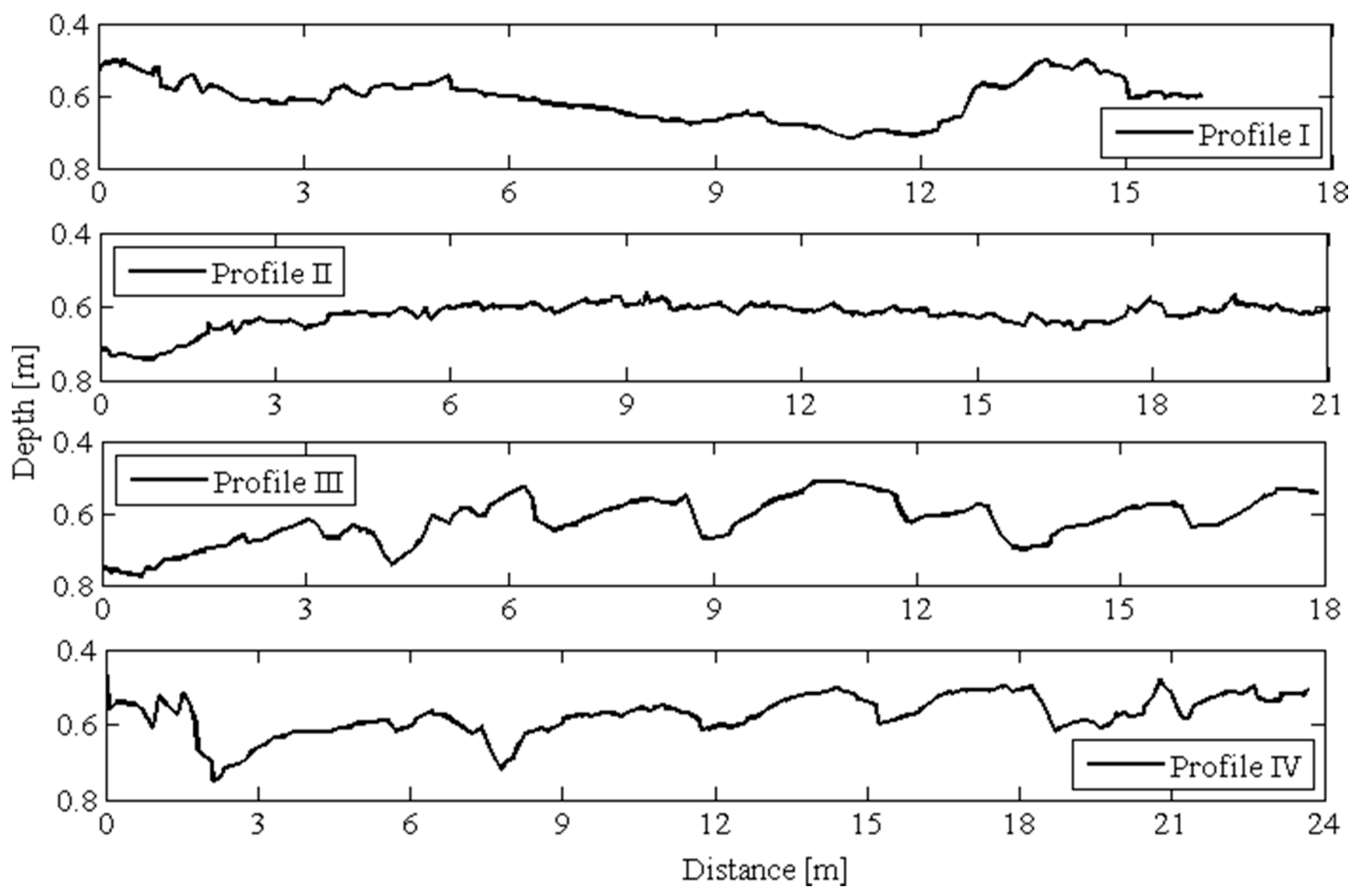

Figure 7. Bed elevation profiles made in the stream-wise direction in the Świder River. Please note that profile numbers increase with distance to the left bank.

\subsection{Velocity Long-Duration Behavior}

The long-duration velocity measurements in two distinct river regions were quasi-stationary, given various phases of sand waves moving beneath, and represent only quantitative differences between those regions and the rivers themselves (Tables 3 and 4). The measured mean longitudinal velocity was higher in the clear flow path in the Jeziorka and Świder rivers by $12 \%$ and $16 \%$, respectively, with mean squared error two times higher in the latter (Table 3). The lateral and vertical velocity fluctuations were also higher in the clear area in the Świder River, while in the Jeziorka River there was no difference between regions (Table 3). The normalized turbulence intensities in the Świder showed increased mixing in longitudinal and vertical directions (higher in clear region than in vegetated region), in contrast to the Jeziorka River, where lateral mixing increased with no differences between regions (Table 3). The turbulent kinetic energy was the highest in the clear region in the Swider River, three times higher than in the other three regions. The normal stresses in the clear region of the Świder River were larger than those in the vegetated area (Table 4), particularly the shear stress ( $\left.\mathrm{U}^{\prime} \mathrm{W}^{\prime}\right)$, which showed typical values as reported by Sukhodolov et al. [27] above the bed with a sandbar of similar height (albeit immobile). The ratio of normal transverse and vertical stresses was close to 1.65 for the Jeziorka River, which is consistent with the coefficient for open channel flows found by Nezu and Nakagawa [50]. The fluctuating longitudinal velocity power spectral density (PSD) plot (Figure 8) showed the occurrence of a $-5 / 3$ Kolmogorov scaling range at higher frequencies, and a -1 scaling range at lower frequencies, which are attributed to the inertial and production subranges of turbulence, respectively [51]. In the Jeziorka River, there were no apparent differences in the PSD between the clear and vegetated regions, in contrast to the Świder River, where the PSD was flatter for the region with plants. 

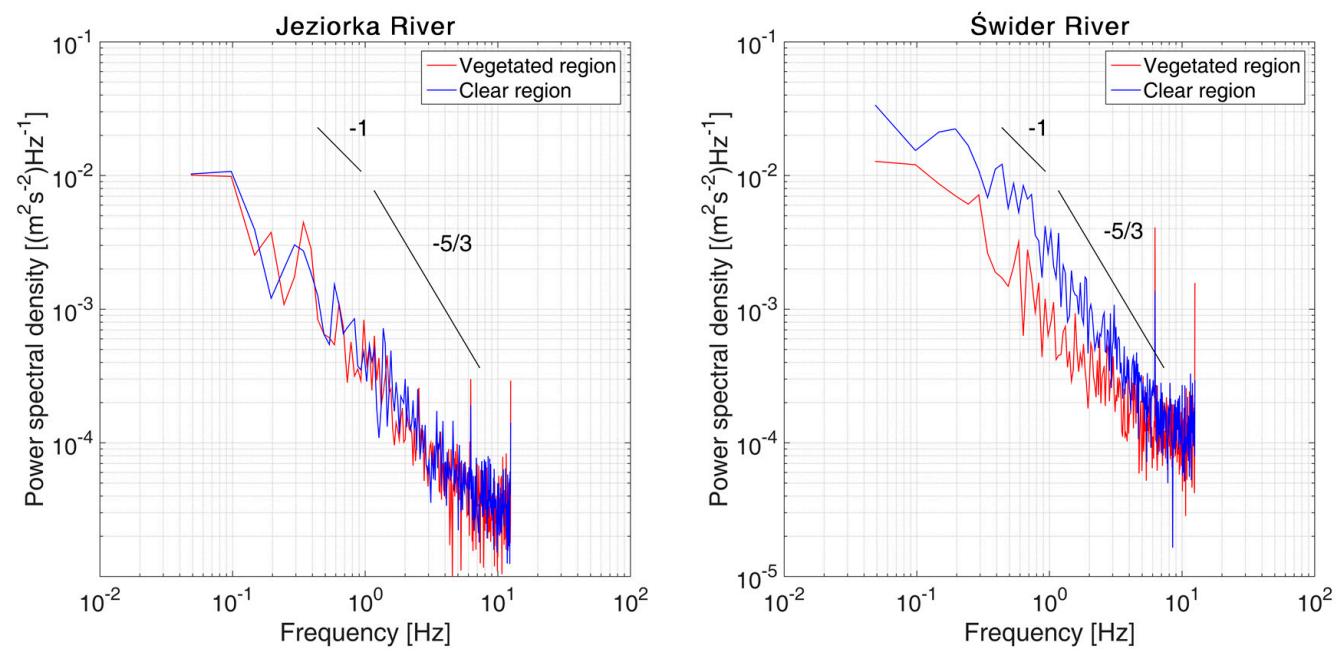

Figure 8. Power spectrum of longitudinal velocities calculated from the filtered signal of long-duration measurements.

Table 3. Mean velocity, turbulence intensity, and turbulent kinetic energy of long-time measurements.

\begin{tabular}{|c|c|c|c|c|c|c|c|c|}
\hline \multirow{2}{*}{\multicolumn{2}{|c|}{ Location }} & \multicolumn{3}{|c|}{$\begin{array}{c}\text { Mean Velocity } \pm \text { SD } \\
\left(\mathrm{cm} \cdot \mathrm{s}^{-1}\right)\end{array}$} & \multicolumn{3}{|c|}{$\begin{array}{l}\text { Turbulence Intensity } \\
\text { (Normalized) }\end{array}$} & \multirow{2}{*}{$\begin{array}{c}\text { Turbulent } \\
\text { Kinetic } \\
\text { Energy } \\
\left(\mathrm{m}^{2} \cdot \mathrm{s}^{-2}\right)\end{array}$} \\
\hline & & $u$ & $V$ & $W$ & $\frac{\sqrt{\overline{U^{\prime 2}}}}{\bar{U}}$ & $\frac{\sqrt{\overline{V^{\prime 2}}}}{\bar{U}}$ & $\frac{\sqrt{\overline{W^{\prime 2}}}}{\bar{U}}$ & \\
\hline \multirow{2}{*}{ Świder R. } & Vegetated & $34.95 \pm 9.61$ & $-4.52 \pm 5.90$ & $0.52 \pm 4.25$ & 0.2115 & 0.0437 & 0.1000 & 0.0032 \\
\hline & Clear & $40.56 \pm 15.14$ & $-5.81 \pm 10.05$ & $-5.56 \pm 8.41$ & 0.2851 & 0.0628 & 0.1972 & 0.0102 \\
\hline \multirow{2}{*}{ Jeziorka R. } & Vegetated & $39.46 \pm 6.18$ & $8.05 \pm 4.90$ & $-0.62 \pm 3.53$ & 0.1521 & 0.1186 & 0.0885 & 0.0035 \\
\hline & Clear & $44.25 \pm 6.21$ & $3.28 \pm 4.81$ & $-2.95 \pm 3.66$ & 0.1345 & 0.1011 & 0.0816 & 0.0034 \\
\hline
\end{tabular}

Table 4. Mean velocity, turbulence intensity, and turbulent kinetic energy of long-time measurements.

\begin{tabular}{|c|c|c|c|c|c|c|c|}
\hline \multirow{3}{*}{\multicolumn{2}{|c|}{ Location }} & \multicolumn{6}{|c|}{ Reynolds Stresses $\left(\mathrm{kg} \cdot \mathrm{m}^{-1} \cdot \mathrm{s}^{-2}\right)$} \\
\hline & & \multicolumn{3}{|c|}{ Normal Stresses } & \multicolumn{3}{|c|}{ Tangential Stresses } \\
\hline & & $-æ \overline{u^{\prime} u^{\prime}}$ & $-\mathfrak{æ} \overline{v^{\prime} v^{\prime}}$ & $-æ \overline{w^{\prime} w^{\prime}}$ & $-æ \overline{u^{\prime} v^{\prime}}$ & $-æ \overline{u^{\prime} w^{\prime}}$ & $-æ \overline{v^{\prime} w^{\prime}}$ \\
\hline \multirow{2}{*}{ Świder R. } & Vegetated & -5.46 & 0.23 & -1.22 & -0.27 & 0.91 & 0.28 \\
\hline & Clear & -13.37 & -0.65 & -6.40 & 1.72 & 5.68 & -0.93 \\
\hline \multirow{2}{*}{ Jeziorka R. } & Vegetated & -3.60 & -2.19 & -1.22 & 0.67 & 0.75 & -0.03 \\
\hline & Clear & -3.54 & -2.00 & -1.30 & -0.04 & 0.81 & -0.13 \\
\hline
\end{tabular}

\subsection{Velocity Profiles in the Proximity of P. pectinatus}

The mean longitudinal velocities upstream of $P$. pectinatus were distributed in the expected logarithmic profile, with a maximum value of $0.58 \mathrm{~m} \cdot \mathrm{s}^{-1}$ (Figure 9). Two downstream profiles were similar in each velocity direction, but with increased deviations below $\mathrm{Z} / \mathrm{H}=0.3$, especially for the profile $0.25 \mathrm{~m}$ behind the plant. The profile upstream had increased mean lateral velocity and vertical velocity oscilating near $0 \mathrm{~m} \cdot \mathrm{s}^{-1}$, while downstream of the plant the velocity tended to be directed toward the bottom. The turbulent kinetic energy was elevated at a height of $\mathrm{Z} / \mathrm{H}=0.1$ upstream of the plant, but downstream it was lower at that height (Figure 9). 

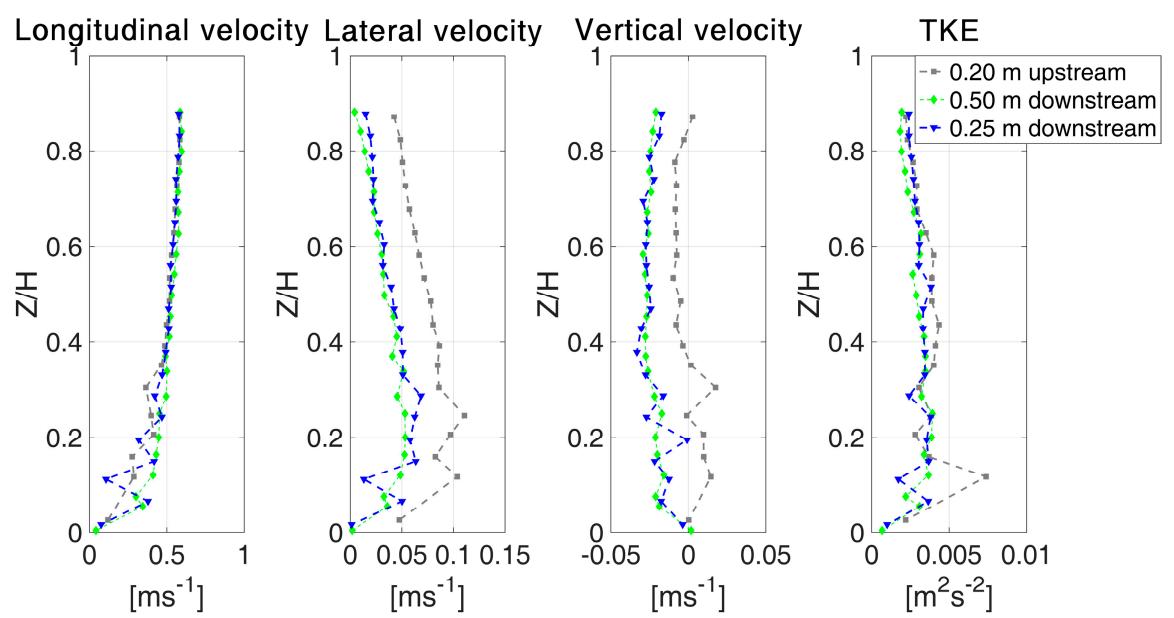

Figure 9. Profiles from the Jeziorka River upstream and downstream of P. pectinatus.

\subsection{Biomechanical Measurements}

P. pectinatus samples from the Jeziorka River were characterized by thinner stems than those collected from the Świder River. The mean diameters in the three-point bending tests were 0.99 and $1.14 \mathrm{~mm}$ for hydrophytes from the Jeziorka and the Świder rivers, respectively (Table 5), whereas in the tension tests, these values ranged from $0.98 \mathrm{~mm}$ for species from the Jeziorka to $1.33 \mathrm{~mm}$ for individuals from the Świder (Table 6). The maximum force, maximum stress, and flexural strain were similar for both locations (Table 5). However, P. pectinatus from the Jeziorka River was characterized by lower flexural rigidity and flexural modulus of $7.82 \mathrm{~N} \cdot \mathrm{mm}^{2}$ and $175.20 \mathrm{MPa}$, respectively (Table 5). The same species from the Świder River had a stiffness that was approximately twice as high: The flexural rigidity was $16.09 \mathrm{~N} \cdot \mathrm{mm}^{2}$ (Table 5). The flexural modulus was also much higher, reaching $280.39 \mathrm{MPa}$.

The tension test results show that the breaking force of P. pectinatus from the Jeziorka River was higher, 3.32 N compared to the value associated with the Świder River, $2.34 \mathrm{~N}$ (Table 6). The differences in strength were more prominent; the plant from the first experiment had a breaking stress of $4.56 \mathrm{MPa}$, whereas the value was lower for the second plant, at $1.91 \mathrm{MPa}$ (Table 6). The strain of the studied species from the Jeziorka River was $12.33 \%$, whereas for hydrophytes from the Świder River, the strain was $9.08 \%$. P. pectinatus displayed a mean Young's modulus of $104.50 \mathrm{MPa}$ in the plants from the first measurement and $38.17 \mathrm{MPa}$ in the plants from the second (Table 6).

Table 5. Diameter and three-point bending test results for P. pectinatus.

\begin{tabular}{|c|c|c|c|c|c|}
\hline \multirow{3}{*}{\multicolumn{2}{|c|}{ Parameter }} & \multicolumn{2}{|c|}{ Jeziorka River } & \multicolumn{2}{|c|}{ Świder River } \\
\hline & & \multicolumn{2}{|c|}{5 July } & \multicolumn{2}{|c|}{1 October } \\
\hline & & \multicolumn{2}{|c|}{20 Samples } & \multicolumn{2}{|c|}{22 Samples } \\
\hline & & Mean \pm SD & Median & Mean \pm SD & Median \\
\hline Diameter & $(\mathrm{mm})$ & $0.99 \pm 0.17$ & 0.99 & $1.14 \pm 0.31$ & 1.01 \\
\hline Maximum force & $(\mathrm{N})$ & $0.022 \pm 0.007$ & 0.020 & $0.024 \pm 0.017$ & 0.020 \\
\hline Maximum stress & (MPa) & $0.030 \pm 0.013$ & 0.025 & $0.023 \pm 0.010$ & 0.023 \\
\hline Flexural strain & $(\%)$ & $4.38 \pm 1.02$ & 4.27 & $4.52 \pm 1.73$ & 4.33 \\
\hline Max. deflection & $(\mathrm{mm})$ & $16.14 \pm 1.55$ & 16.13 & $14.57 \pm 2.97$ & 15.62 \\
\hline Sec. m. of area & $\left(\mathrm{mm}^{4}\right)$ & $0.057 \pm 0.049$ & 0.046 & $0.131 \pm 0.209$ & 0.051 \\
\hline Flexural rigidity & $\left(\mathrm{N} \cdot \mathrm{mm}^{2}\right)$ & $7.82 \pm 4.22$ & 6.22 & $16.09 \pm 5.27$ & 16.07 \\
\hline Flexural modulus & $(\mathrm{MPa})$ & $175.20 \pm 91.49$ & 159.80 & $280.39 \pm 188.84$ & 271.75 \\
\hline
\end{tabular}


Table 6. Diameter and tension test results for P. pectinatus.

\begin{tabular}{cccccc}
\hline \multirow{2}{*}{\multicolumn{2}{c}{ Parameter }} & & \multicolumn{2}{c}{ Jeziorka River } & \multicolumn{2}{c}{ Świder River } \\
\cline { 3 - 6 } & & \multicolumn{2}{c}{ 5 July } & \multicolumn{2}{c}{ 1 October } \\
\cline { 3 - 6 } & & \multicolumn{2}{c}{ 20 Samples } & \multicolumn{2}{c}{ 19 Samples } \\
\cline { 3 - 6 } & & Mean \pm SD & Median & Mean \pm SD & Median \\
\hline Diameter & $(\mathrm{mm})$ & $0.98 \pm 0.12$ & 1.00 & $1.33 \pm 0.35$ & 1.28 \\
Breaking force & $(\mathrm{N})$ & $3.32 \pm 0.63$ & 3.45 & $2.34 \pm 0.77$ & 2.22 \\
Breaking stress & $(\mathrm{MPa})$ & $4.56 \pm 1.30$ & 4.63 & $1.91 \pm 0.95$ & 1.62 \\
Breaking strain & $(\%)$ & $12.33 \pm 3.42$ & 13.18 & $9.08 \pm 2.17$ & 8.84 \\
Young's modulus & $(\mathrm{MPa})$ & $104.50 \pm 35.19$ & 104.00 & $38.17 \pm 26.01$ & 35.83 \\
\hline
\end{tabular}

\section{Discussion}

The typical configuration of aquatic plants found in both studied rivers consisted of a strip of plants growing along the river bank, similar to the configuration observed in the study by Naden et al. [24]. We expect aquatic macrophytes to grow closer to river banks due to the favorable conditions for seeds to be trapped [52]. In the case of P. pectinatus, Chambers et al. [53] showed that it thrives in rivers with slower currents; therefore, in the vegetated region, the water current was expected to be lower than in the main stream due to the plant's growth requirements. This theory was borne out by the obtained results, with measured velocity being $12 \%$ and $16 \%$ lower than that in the clear regions in the Świder and Jeziorka rivers, respectively (Table 3). However, the study of Kemp et al. [54] showed that submerged macrophytes with fine leaves thrive in habitats with a wide range of Froude numbers.

The investigated rivers exhibited similar granulometry (Figure 1), but the Świder River had a Froude number two times greater (Table 1), and it produced different sand wave patterns. In the Jeziorka River, approximately $20 \%$ of the width of the studied cross-section was considered the vegetated region, while in the Świder River, the living plants spread to no more than $10 \%$ of the channel width. Note that the experiments were conducted in meandering rivers, which is reflected in the cross-sectional structure (Figure 4), and which in turn had a major influence on bed scour and deposition $[55,56]$. Three regions were distinguished in both rivers: The relatively flat, deepest region with vegetation, a middle region without plants but with sand forms, and a shallow region opposite the deep one (Figure 4), which in the Jeziorka River was also vegetated. This pattern of deep and shallow fragments of a channel, a sequence of pools and riffles, is typical for natural meandering rivers [57-59]. However, the pattern of plant patches in a channel varies not only yearly but also seasonally, changing the bed shear stress over time $[18,24]$. Furthermore, the occurrence of plants and flattening of sand waves may be connected to the appearance of dead wood debris, which was found in the vegetated regions in both rivers, as this type of debris can trap seeds and organic matter [60]. Submerged vegetation in this case performs a similar role as emergent or riparian vegetation: Trapping fine sediment, building landforms, and ultimately stabilizing the river banks $[19,61,62]$. This hypothesis is consistent with the occurrence of sandbars, visible in vegetated regions near banks in both rivers (Figure 4). These bars could serve as plant-rooting locations, where vegetation decreases the flow velocity within the patch and increases it around the main body of the plant [63]. The present case study revealed that sparsely rooted plant specimens did not create blockage factor big enough to deflect flow and scouring effect was not observed, which otherwise would protect a plant from being buried by passing sand forms.

The collected records of bed elevation changes show differences between various regions in river cross-section morphology in terms of the discrete characterization method. The Jeziorka River featured completely disturbed sand waves in the vegetated region (Figure 5), while in the Świder River, these waves occurred in the vicinity of P. pectinatus; however, these dunes were three times lower than the fully developed wave forms in the clear region (Figure 6). The bed form celerity shows that larger dunes were migrating at slower rate than ripples close to the river bank (Table 2). Large bed forms contain more bed load, therefore a significant part of the sediment must be transported in the clear 
region of the river through dune movements [64]. The flow in that region was characterized by higher Reynolds stresses due to higher shear caused by larger dunes and higher mean longitudinal velocity, however reduced in the dune trough (Figure 6), which is in line with those of, e.g., Venditti and Bauer [65] and Kostaschuk [66]. In comparison to the study of Sukhodolov et al. [27], mean Reynolds shear stress was 10 times higher in spite of the same mean velocity, however it can be explained by the fact that measured point in the present case study in the Świder River was relatively close to the bottom and a lot of negative velocities were recorded, which was not the case in study of Sukholodov [27].

A spike visible in the power spectral density plot in the clear region of the Świder River at $0.4-0.5 \mathrm{~Hz}$ (Figure 8) can be related to eddy-like flow structures that originated from the flow separation zone in the lee side of the dune [50]. However, Venditti and Bauer [65] indicated that eddies could not be attributed to a certain frequency, and what is more, analysis of a long-duration velocity power spectrum can be misleading due to the occurrence of local nonstationarity in the time series (particularly prominent in Figure 6). Furthermore, Singh et al. [67] reported that eddies with a vertical size smaller than the distance from the bottom to the measurement point could not be found in the spectra at all. Nevertheless, the spectrum of the velocity in the vegetated region in the Świder River was flatter in the inertial subrange than in the clear region. Consequently, more energy was conducted into higher frequencies in the clear region, as would be expected in the dissipation wake of a bed form [65]. The elevated Reynolds stress in that clear region (Table 4) was also in agreement with the observation of energy distribution. Obtained results indicate that there was a connection between the height of sand dunes and Reynolds shear stress in the water layer above. However, in the pool region, Reynolds stress distribution might be not correlated with sediment size or flow characteristics [59].

Plants, even of the same species, that grow in similar rivers can be characterized by changes in biomechanical properties that depend on the habitat conditions and the phase of plant growth [68]. P. pectinatus from two investigated rivers differed in terms of length, thickness, and biomechanical traits. Hydrophytes from the Świder River were shorter, thicker, and stiffer (Tables 5 and 6), and were more resistant to bending forces than specimens from the Jeziorka River. Nevertheless, they were more durable in the tension tests (Table 6). In other words, the specimens growing in the region where the bed was flat grew longer and had altered characteristics such that they were more prone to bend to withstand higher forces resulting from their length. This behavior may be an example of an avoidance strategy, as described by Puijalon et al. [69]. The occurrence of drag on a simple specimen was visible in the measured velocity profiles (Figure 9), in which a region of disturbed velocities in the plant wake was noted. In the Świder River, the increased resistance to bending by specimens growing out of the riverbed, where the ripples were as high as the plants themselves, may be a natural strategy to withstand unfavorable conditions. Then, the most likely reason for the above-mentioned differences in biomechanical properties of hydrophytes may be connected to their diversity of growth phases [68].

The question arises as to whether the studied plants affect the flow and sediment movements or vice versa. The measurements in the Jeziorka River revealed lower mean longitudinal and lateral velocities in the wake of the single plant, but most outstanding was the lower TKE relative to that of the point upstream (Figure 9). The TKE results were not consistent with those obtained by Biggs et al. [70] with another hydrophyte of similar morphology, Ranunculus penicillatus (Dumort.) Bab., for which TKE was elevated. However, that study focused on a dense patch and not on a thin individual plant. In the Jeziorka River, the studied macrophyte was streamlining, which is a natural behavior for flexible plants in high-flow conditions [71,72]. Moreover, Siniscalchi and Nikora [72] showed that single hydrophytes exhibited flapping-like motions to minimize drag force, indicating their susceptibility to turbulent eddies [63]. With the frontal area of P. pectinatus being approximately four times smaller than that of the patch in Biggs's experiment, the effect on flow in the plant's wake was barely discernible (Figure 9). The studied individuals were too small to show any effect on the bottom morphology; however, there were denser patches downstream (Figure 2), which were followed by a shallower area (Figure 4). In the Świder River, plants grew too small and sparsely to have a significant impact on the velocity profile or bed shear stress (canopies of a $/ \mathrm{h}<<0.1$, where $a$ is diameter and $h$ is water height; see [71]) 
or even on the sand forms; therefore, plants were periodically covered by migrating dunes, as we observed in our measurements. This result is consistent with a theory by Green [63], who suggested that certain hydrophytes in regions close to the bank and the riverbed do not contribute significantly to resistance due to drag of the boundary layer itself. The present case study investigated such species with even lower shoot density and more sharp-ended stems than R. penicillatus, which have practically no blockage effect. This can be a hint, which species are likely to positively contribute to biodiversity of river but not significantly affect flow resistance. Furthermore, Chen and Kao [73] showed that flow through sparse vegetation was similar to flow that occurs in a solid-boundary channel.

Studies performed in situ by Naden et al. [24] and Sukhodolova and Sukhodolov [74] represent a goal for how studies of flow-biota-sediment interactions should be conducted. The present investigation was smaller in scale and details, as the requirement of maintaining stationarity of the measurement and revision of local conditions forced us to skip some of the observations. In spite of this, the findings of the presented study show agreement with general theories on this subject and add scarcely available data to it. Therefore, the next step would be to perform subsequent measurements in the next summer season in the same spots to observe changes in bed morphology and vegetation cover. Additionally, the creation of a denser grid of velocity profiles around P. pectinatus patches, including big canopies present in the Jeziorka River, would be preferable in order to find how these plants' assembles affect flow field.

\section{Conclusions}

We present the following observations with regard to the plant occurrence, sediment movements, plant traits, and effects of hydrophytes on flow and sand forms:

- The aquatic plant P. pectinatus grew in a larger quantity in the river with the lower Reynolds number, tending to be located in a pool section of a channel, where smaller ripples occurred. This finding suggests an emerging pattern in which flow conditions and bed morphology are connected with the occurrence of the studied hydrophyte.

- The bed forms measured in the Świder River tended to exhibit increased height and length with increased distance from the vegetated region close to the bank. These forms were also more developed than those in the Jeziorka River, which is characterized by finer sediment and faster but steadier flow, with lower turbulent kinetic energy and a lower Froude number.

- Major differences were identified in the plants' morphology and biomechanics: Older individuals from the faster-flowing Świder River were thicker, shorter, and stiffer than their younger counterparts from the Jeziorka River, which were more prone to bending. These traits may have resulted from the aquatic macrophytes' adjustment to the habitat conditions.

- Strips of short individual P. pectinatus plants within a mobile bed in the Świder River did not seem to detectably affect passing sand ripples. Turbulence statistics suggest a much steadier flow than that in the clear area.

- The single hydrophyte from the Jeziorka River did not affect the velocities measured downstream; only elevated TKE was visible in the wake of the plant.

- The mean velocity in front of the plants was approximately $12 \%$ and $16 \%$ lower than in the clear regions in the Świder River and Jeziorka River, respectively. Therefore, bed conditions such as small sandbars and wood debris trapping organic material could have made major contributions to the creation of a habitat suitable for plants to grow. 
Author Contributions: Ł.P., A.M.Ł., and R.J.B. designed the study and carried out the field experiments. Ł.P. conducted the majority of the data analysis and wrote the majority of the paper. A.M.Ł. and Ł.P. carried out the biomechanical tests and granulometry. A.M.Ł. described and analyzed the biomechanical test results and prepared bed morphology maps. R.J.B. prepared and depicted bed elevation data. All authors contributed to the final version of the manuscript.

Funding: The research was funded by the National Science Centre, Poland, Grant No. UMO-2014/13/D/ST10/01123 'Field experimental investigation of hydrodynamics of water flow-vegetation-sediment interactions at the scale of individual aquatic plants'.

Acknowledgments: The publication has been partially financed from the funds of the Leading National Research Centre (KNOW) received by the Centre for Polar Studies for the period 2014-2018. We sincerely thank our colleague, Mikołaj Karpiński, for all the help and comments with regard to preparing and conducting field measurements.

Conflicts of Interest: The authors declare no conflicts of interest.

\section{References}

1. Aberle, J.; Järvelä, J. Hydrodynamics of vegetated channels. In Rivers_Physical, Fluvial and Environmental Processes; Rowiński, P., Radecki-Pawlik, A., Eds.; Springer International Publishing: Cham, Switzerland, 2015; pp. 519-541. ISBN 978-3-319-17718-2.

2. Ormerod, S.J.; Rundle, S.D.; Lloyd, E.C.; Douglas, A.A. The influence of riparian management on the habitat structure and macroinvertebrate communities of upland streams draining plantation forests. J. Appl. Ecol. 1993, 13-24. [CrossRef]

3. McKenney, R.; Jacobson, R.B.; Wertheimer, R.C. Woody vegetation and channel morphogenesis in low-gradient, gravel-bed streams in the Ozark Plateaus, Missouri and Arkansas. Geomorphology 1995, 13, 175-198. [CrossRef]

4. Simon, A.; Collison, A.J. Quantifying the mechanical and hydrologic effects of riparian vegetation on streambank stability. Earth Surf. Process. Landf. 2002, 27, 527-546. [CrossRef]

5. Nikora, V. Hydrodynamics of aquatic ecosystems: An interface between ecology, biomechanics and environmental fluid mechanics. River Res. Appl. 2010, 26, 367-384. [CrossRef]

6. Folkard, A.M. Vegetated flows in their environmental context: A review. Proc. Inst. Civ. Eng. Eng. Comput. Mech. 2011, 164, 3-24. [CrossRef]

7. Nepf, H.M. Hydrodynamics of vegetated channels. J. Hydraul. Res. 2012, 50, 262-279. [CrossRef]

8. Yager, E.M.; Schmeeckle, M.W. The influence of vegetation on turbulence and bed load transport. J. Geophys. Res. Earth Surf. 2013, 118, 1585-1601. [CrossRef]

9. O'Hare, M.T.; Mountford, J.O.; Maroto, J.; Gunn, I.D.M. Plant traits relevant to fluvial geomorphology and hydrological interactions. River Res. Appl. 2016, 32, 179-189. [CrossRef]

10. Reid, M.A.; Thoms, M.C. Surface flow types, near-bed hydraulics and the distribution of stream macroinvertebrates. Biogeosciences 2008, 5, 1175-1204. [CrossRef]

11. Osterkamp, W.R.; Hupp, C.R.; Stoffel, M. The interactions between vegetation and erosion: New directions for research at the interface of ecology and geomorphology. Earth Surf. Process. Landf. 2012, 37, $23-36$. [CrossRef]

12. James, C.S.; Jordanova, A.A.; Nicolson, C.R. Flume experiments and modelling of flow-sediment-vegetation interactions. In Structure, Function and Management Implications of Fluvial Sedimentary Systems; Proceedings of the Symposium on the Structure, Function and Management Implications of Fluvial Sedimentary Systems, Alice Springs, Australia, 2-6 September 2002; Dyer, F.J., Thoms, M.C., Olley, J.M., Eds.; International Association of Hydrological Sciences, Publication, Institute of Hydrology: Wallingford, UK, 2002; Volume 276, pp. 3-9.

13. Rominger, J.T.; Lightbody, A.F.; Nepf, H.M. Effects of added vegetation on sand bar stability and stream hydrodynamics. J. Hydraul. Eng. 2010, 136, 994-1002. [CrossRef]

14. Liu, C.; Hu, Z.; Lei, J.; Nepf, H. Vortex Structure and Sediment Deposition in the Wake behind a Finite Patch of Model Submerged Vegetation. J. Hydraul. Eng. 2017, 144, 04017065. [CrossRef]

15. Bouma, T.J.; van Duren, L.A.; Temmerman, S.; Claverie, T.; Blanco-Garcia, A.; Ysebaert, T.; Herman, P.M.J. Spatial flow and sedimentation patterns within patches of epibenthic structures: Combining field, flume and modelling experiments. Cont. Shelf Res. 2007, 27, 1020-1045. [CrossRef] 
16. Schnauder, I.; Sukhodolov, A.N. Flow in a tightly curving meander bend: Effects of seasonal changes in aquatic macrophyte cover. Earth Surf. Process. Landf. 2012, 37, 1142-1157. [CrossRef]

17. Cavedon, V. Effects of Rigid Stems on Sediment Transport. Ph.D. Dissertation, University of Trento, Trento, Italy, 2012.

18. Cassan, L.; Belaud, G.; Baume, J.P.; Dejean, C.; Moulin, F. Velocity profiles in a real vegetated channel. Environ. Fluid Mech. 2015, 15, 1263-1279. [CrossRef]

19. Gurnell, A.M.; Grabowski, R.C. Vegetation-Hydrogeomorphology Interactions in a Low-Energy, Human-Impacted River. River Res. Appl. 2016, 32, 202-215. [CrossRef]

20. O’Hare, J.M.; O'Hare, M.T.; Gurnell, A.M.; Scarlett, P.M.; Liffen, T.; McDonald, C. Influence of an ecosystem engineer, the emergent macrophyte Sparganium erectum, on seed trapping in lowland rivers and consequences for landform colonisation. Freshw. Biol. 2012, 57, 104-115. [CrossRef]

21. Sand-Jensen, K. Drag forces on common plant species in temperate streams: Consequences of morphology, velocity and biomass. Hydrobiologia 2008, 610, 307-319. [CrossRef]

22. Ghisalberti, M.; Nepf, H. Shallow flows over a permeable medium: The hydrodynamics of submerged aquatic canopies. Transp. Porous Media 2009, 78, 309-326. [CrossRef]

23. Nikora, N.; Nikora, V.; O'Donoghue, T. Velocity profiles in vegetated open-channel flows: Combined effects of multiple mechanisms. J. Hydraul. Eng. 2013, 139, 1021-1032. [CrossRef]

24. Naden, P.; Rameshwaran, P.; Mountford, O.; Robertson, C. The influence of macrophyte growth, typical of eutrophic conditions, on river flow velocities and turbulence production. Hydrol. Process. 2006, 20, 3915-3938. [CrossRef]

25. Sukhodolov, A.N. Field-based research in fluvial hydraulics: Potential, paradigms and challenges. J. Hydraul. Res. 2015, 53, 1-19. [CrossRef]

26. Nikora, V.; Goring, D. Flow turbulence over fixed and weakly mobile gravel beds. J. Hydraul. Eng. 2000, 126, 679-690. [CrossRef]

27. Sukhodolov, A.N.; Fedele, J.J.; Rhoads, B.L. Structure of flow over alluvial bedforms: An experiment on linking field and laboratory methods. Earth Surf. Process. Landf. 2006, 31, 1292-1310. [CrossRef]

28. Chanson, H. Acoustic Doppler velocimetry (ADV) in the field and in laboratory: Practical experiences. In Proceedings of the International Meeting on Measurements and Hydraulics of Sewers IMMHS'08, Summer School GEMCEA/LCPC, Bouguenais, France, 19-21 August 2008; Larrarte, F., Chanson, H., Eds.; Department of Civil Engineering, The University of Queensland: Brisban, Australia, 2008; pp. 49-66.

29. Yagci, O.; Kabdasli, M.S. The impact of single natural vegetation elements on flow characteristics. Hydrol. Process. 2008, 22, 4310-4321. [CrossRef]

30. Thomas, R.E.; McLelland, S.J. The impact of macroalgae on mean and turbulent flow fields. J. Hydrodyn. 2015, 27, 427-435. [CrossRef]

31. Przyborowski, Ł.; Łoboda, A.M.; Karpiński, M.; Bialik, R.J. Characteristics of flow around aquatic plants in natural conditions: Experimental setup, challenges and difficulties. In Free Surface Flows and Transport Processes; Kalinowska, M.B., Mrokowska, M.M., Rowiński, P.M., Eds.; Springer International Publishing: Cham, Switzerland, 2018; pp. 347-361. ISBN 978-3-319-70914-7.

32. Thomas, R.E.; Schindfessel, L.; McLelland, S.J.; Creëlle, S.; De Mulder, T. Bias in mean velocities and noise in variances and covariances measured using a multistatic acoustic profiler: The Nortek Vectrino Profiler. Meas. Sci. Technol. 2017, 28. [CrossRef]

33. Nikora, V.I.; Sukhodolov, A.N.; Rowiński, P.M. Statistical sand wave dynamics in one-directional water flows. J. Fluid Mech. 1997, 351, 17-39. [CrossRef]

34. Coleman, S.E.; Nikora, V.I. Fluvial dunes: Initiation, characterization, flow structure. Earth Surf. Process. Landf. 2011, 36, 39-57. [CrossRef]

35. Kłosowski, S.; Kłosowski, G. Aquatic and Marsh Plants; MULTICO: Warsaw, Poland, 2007; ISBN 9788377633557. (In Polish)

36. Łoboda, A.M.; Przyborowski, Ł.; Karpiński, M.; Bialik, R.J.; Nikora, V.I. Biomechanical properties of aquatic plants: The effect of test conditions. Limnol. Oceanogr. Methods. 2018, 16, 222-236. [CrossRef]

37. Niklas, K.J. Plant Biomechanics. In An Engineering Approach to Plant Form and Function; University of Chicago Press: Chicago, IL, USA, 1992; ISBN 0-226-58641-6.

38. ASTM D790-03. Standard Test Methods for Flexural Properties of Unreinforced and Reinforced Plastics and Electrical Insulating Materials; ASTM International: West Conshohocken, PA, USA, 2003. 
39. MacVicar, B.; Dilling, S.; Lacey, J. Multi-instrument turbulence toolbox (MITT): Open-source MATLAB algorithms for the analysis of high-frequency flow velocity time series datasets. Comput. Geosci. 2014, 73, 88-98. [CrossRef]

40. Brand, A.; Noss, C.; Dinkiel, C.; Holzner, M. High-resolution measurements of turbulent flow close to the sediment-water interface using bistatic acoustic profiler. J. Atmos. Ocean. Technol. 2016, 33, 769-788. [CrossRef]

41. Koca, K.; Noss, C.; Anlanger, C.; Brand, A.; Lorke, A. Performance of the Vectrino Profiler at the sediment-water interface. J. Hydraul. Res. 2017, 55, 573-581. [CrossRef]

42. Goring, D.G.; Nikora, V.I. Despiking Acoustic Doppler Velocimeter data. J. Hydraul. Eng. 2002, 128, 117-126. [CrossRef]

43. Wahl, T.L. Discussion of 'Despiking acoustic Doppler velocimeter data' by Derek G. Goring and Vladimir I. Nikora. J. Hydraul. Eng. 2003, 126, 484-487. [CrossRef]

44. Parsheh, M.; Sotiropoulos, F.; Porte-Agel, F. Estimation of Power Spectra of Acoustic-Doppler Velocimetry Data Contaminated with Intermittent Spikes. J. Hydraul. Eng. ASCE 2010, 136, 368-378. [CrossRef]

45. Voulgaris, G.; Trowbridge, J.H. Evaluation of the acoustic Doppler velocimeter (ADV) for turbulence measurements. J. Atmos. Ocean. Tech. 1998, 15, 272-289. [CrossRef]

46. Hurther, D.; Lemmin, U. A correction method for turbulence measurements with a 3D acoustic Doppler velocity profiler. J. Atmos. Ocean. Tech. 2001, 18, 446-458. [CrossRef]

47. Welch, P.D. The use of fast Fourier transform for the estimation of power spectra: A method based on time averaging over short, modified periodograms. IEEE Trans. Acoust. Electr. 1967, 15, 70-73. [CrossRef]

48. Tuijnder, A.P.; Ribberink, J.S.; Hulscher, S.J. An experimental study into the geometry of supply-limited dunes. Sedimentology 2009, 56, 1713-1727. [CrossRef]

49. Bialik, R.; Karpiński, M.; Rajwa, A.; Luks, B.; Rowiński, P. Bedform characteristics in natural and regulated channels: A comparative field study on the Wilga River, Poland. Acta Geophys. 2014, 62, 1413-1434. [CrossRef]

50. Nezu, I.; Nakagawa, H. Turbulence in Open-Channel Flows, 1st ed.; CRC Press: Boca Raton, FL, USA, 1993; ISBN 9054101180.

51. Nikora, V. Origin of the "-1" spectral law in wall-bounded turbulence. Phys. Rev. Lett. 1999, 83, 734. [CrossRef]

52. Gurnell, A.; Goodson, J.; Thompson, K.; Clifford, N.; Armitage, P. The river-bed: A dynamic store for plant propagules? Earth Surf. Process. Landf. 2007, 32, 1257-1272. [CrossRef]

53. Chambers, P.A.; Prepas, E.E.; Hamilton, H.R.; Bothwell, M.L. Current velocity and its effect on aquatic macrophytes in flowing waters. Ecol. Appl. 1991, 1, 249-257. [CrossRef] [PubMed]

54. Kemp, J.L.; Harper, D.M.; Crosa, G.A. The habitat-scale ecohydraulics of rivers. Ecol. Eng. 2000, 16, 17-29. [CrossRef]

55. Carling, P.A. An appraisal of the velocity-reversal hypothesis for stable pool-riffle sequences in the River Severn, England. Earth Surf. Process. Landf. 1991, 16, 19-31. [CrossRef]

56. Wilkinson, S.N.; Keller, R.J.; Rutherfurd, I.D. Phase-shifts in shear stress as an explanation for the maintenance of pool-riffle sequences. Earth Surf. Process. Landf. 2004, 29, 737-753. [CrossRef]

57. Tinkler, K.J. Pools, riffles, and meanders. Geol. Soc. Am. Bull. 1970, 81, 547-552. [CrossRef]

58. Church, M. Bed material transport and the morphology of alluvial river channels. Annu. Rev. Earth Planet. Sci. 2006, 34, 325-354. [CrossRef]

59. Najafabadi, E.F.; Afzalimehr, H.; Rowiński, P.M. Flow structure through a fluvial pool-riffle sequence-Case study. J. Hydro-Environ. Res. 2018, 19, 1-15. [CrossRef]

60. Schneider, R.L.; Sharitz, R.R. Hydrochory and Regeneration in A Bald Cypress-Water Tupelo Swamp Forest. Ecology 1998, 69, 1055-1063. [CrossRef]

61. Västilä, K.; Järvelä, J. Characterizing natural riparian vegetation for modeling of flow and suspended sediment transport. J. Soils Sediments 2017, 17, 1-17. [CrossRef]

62. Liu, D.; Valyrakis, M.; Williams, R. Flow Hydrodynamics across Open Channel Flows with Riparian Zones: Implications for Riverbank Stability. Water 2018, 9, 720. [CrossRef]

63. Green, J.C. Modelling flow resistance in vegetated streams: Review and development of new theory. Hydrol. Process. 2005, 19, 1245-1259. [CrossRef] 
64. Aberle, J.; Coleman, S.; Nikora, V. Bed load transport by bed form migration. Acta Geophys. 2012, 60, 1720-1743. [CrossRef]

65. Venditti, J.G.; Bauer, B.O. Turbulent flow over a dune: Green River, Colorado. Earth Surf. Process. Landf. 2005, 30, 289-304. [CrossRef]

66. Kostaschuk, R. A field study of turbulence and sediment dynamics over subaqueous dunes with flow separation. Sedimentology 2000, 47, 519-531. [CrossRef]

67. Singh, A.; Porté-Agel, F.; Foufoula-Georgiou, E. On the influence of gravel bed dynamics on velocity power spectra. Water Resour. Res. 2010, 46. [CrossRef]

68. Łoboda, A.M.; Bialik, R.J.; Karpiński, M.; Przyborowski, Ł. Two simultaneously occurring Potamogeton species: Similarities and differences in seasonal changes of biomechanical properties. Pol. J. Environ. Stud. 2019, 28, 1-17. [CrossRef]

69. Puijalon, S.; Bouma, T.J.; Douady, C.J.; van Groenendael, J.; Anten, N.P.; Martel, E.; Bornette, G. Plant resistance to mechanical stress: Evidence of an avoidance-tolerance trade-off. New Phytol. 2011, 191, 1141-1149. [CrossRef] [PubMed]

70. Biggs, H.; Nikora, V.N.; Papadopoulos, K.; Vettori, D.; Gibbins, C.; Kucher, M. Flow-vegetation interactions: A field study of ranunculus penicillatus at the large patch scale. In Proceedings of the 11th International Symposium on Ecohydraulics, Melbourne, Australia, 7-12 February 2016.

71. Nepf, H.M. Flow and transport in regions with aquatic vegetation. Annu. Rev. Fluid Mech. 2012, 44, 123-142. [CrossRef]

72. Siniscalchi, F.; Nikora, V. Dynamic reconfiguration of aquatic plants and its interrelations with upstream turbulence and drag forces. J. Hydraul. Res. 2013, 51, 46-55. [CrossRef]

73. Chen, Y.C.; Kao, S.P. Velocity distribution in open channels with submerged aquatic plant. Hydrol. Process. 2011, 25, 2009-2017. [CrossRef]

74. Sukhodolova, T.A.; Sukhodolov, A.N. Vegetated mixing layer around a finite-size patch of submerged plants: 1. Theory and field experiments. Water Resour. Res. 2012, 48. [CrossRef]

(C) 2018 by the authors. Licensee MDPI, Basel, Switzerland. This article is an open access article distributed under the terms and conditions of the Creative Commons Attribution (CC BY) license (http:/ / creativecommons.org/licenses/by/4.0/). 